\title{
УТИЦАЈ КЛИМАТСКИХ ПРОМЕНА НА ПОЛИТИЧКЕ НЕМИРЕ И СУКОБЕ У АФРИЦИ: СТУДИЈА СЛУЧАЈА ЕТИОПИЈЕ
}

Гордана Мишев", студенткиња докторских студија Универзитет у Београду, Факултет безбедности 



\section{УТИЦАЈ КЛИМАТСКИХ ПРОМЕНА НА ПОЛИТИЧКЕ НЕМИРЕ И СУКОБЕ У АФРИЦИ: СТУДИЈА СЛУЧАЈА ЕТИОПИЈЕ}

Сажетак: Безбеgносни изазови, ризици и иерет̄юе, йревазилазећи иираgиционалне облике, йостиали су ииолико комитлексни gа је юихово разу-

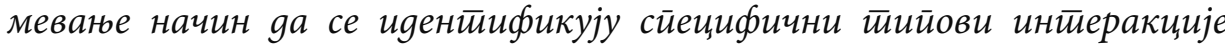
који уірожавају безбеgности. Климайске ирромене и ілобално заіреване могуу иматии озбиљне йослеgице йо тьудско зяравље, соиијални и економ-

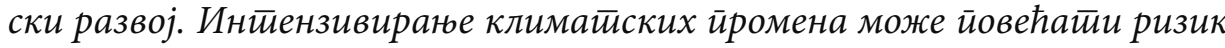
оg иолитиччких немира и конбликайа у gржавама чији је економски и

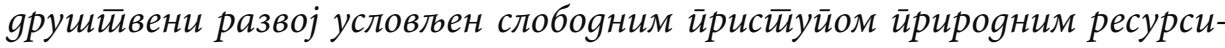
ма. Узрок сукоба никаg није тако оgреgитии, јер је йо скуй различитиих

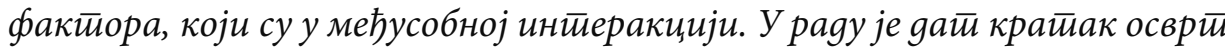
на сукобе у Африци, са йосебним найласком на сукобе у Ейиойији и реїиону, како би се истиакла сложености и међузависности климатиских ирромена и нихових йослеgица на иолийичке одлуке, gрушиивене немире, иринуgне миірације и ірађанске и међунаровне сукобе.

Кључне речи: климайске ирромене, йолитички сукоби, миірације, Африка, Ейиойија. 


\section{Увод}

Безбедност животне средине представља угрожавање политичке стабилности, смањење или превенцију рата или оружаних сукоба који произлазе из еколошких промена, природних несрећа, као и еколошких последица рата (Jovanović Popović, 2013). На деградацију животне средине утиче велики број фактора, било да су настали природним (поплаве, земљотреси), антрополошким путем (индустријски акциденти, загађење ваздуха) или најчешће комбинацијом оба наведена. Може се рећи да је међународна заједница сажела проблем еколошких криза у три сегмента: 1. превенција и спречавање даље деградације животне средине и очување природних ресурса; 2. санација и развој области угрожених еколошким катастрофама и 3. спречавање и решавање сукоба као последица недостатка ресурса и њихове трајне деградације. Научна предвиђања промена у животној средини и последица миграција људи су од суштинског значаја за развој стратегија за дугорочно економско планирање и друштвени развој, као и постизање благостања и просперитета (Parfenova et al., 2019).

У Петом извештају Међувладиног панела о климатским променама (Intergovernmental Panel on Climate Change - IPCC) из 2014. године, наглашавајући утицај антропогених фактора на климатске промене, научници су скренули пажњу да раст температуре повећава вероватноћу разорних утицаја који могу бити изненађујући или неповратни. У овом извештају се наводи да људи и екосистеми широм света имају различит степен рањивости у зависности од региона, обухватајући целу планету, од малих острва до великих континената (IPCC, 2014). У том смислу, економски, политички и друштвени развој земаља Африке отежан је дуготрајном деградацијом животне средине. Чињеница је да климатске промене и деградација животне средине, оружани сукоби и политичке, економске и кризе у вези са храном (недостатак или неприступачност) настављају да присиљавају људе на бег (IOM, 2019).

Канадски научник Томас Хомер Диксон сматра да деградација животне средине већ доприноси насилним сукобима у многим деловима света у развоју, што утиче на рапидно повећање броја еколошких миграната. Пораст броја избеглица је по њему први знак пораста насиља у наредним деценијама, које ће бити изазвано оскудицом и исцрпљивањем природних ресурса. Сиромашна друштва ће бити посебно погођена, јер су мање способна да се одбране од деградације животне средине и социјалних криза (Homer-Dixon, 1994).

Еколошке катастрофе (земљотреси, цунамији, поплаве, ерозије) су огроман изазов безбедности, јер изненадне и акутне промене које пого- 
де одређене територије често доводе до хуманитарне катастрофе, узрокујући бројне људске жртве и нехумане услове живота у тим регионима. У том смислу имамо примере цунамија у Индијском океану 2004, урагана Катрина 2005. и земљотреса у Јапану 2016. године.

Трајне деградације животне средине, као што су суше и салинизација земљишта, највише погађају земље Африке. С друге стране, регион Пацифика је угрожен порастом нивоа мора, а азијске земље ураганима и земљотресима. Забрињава чињеница да су то подручја која обухватају земље с ниским степеном економског развоја, које немају довољно средстава да се ефикасно боре са деградацијом животне средине, а додатно су дестабилизоване политичким сукобима. Регија Блиског истока и Северне Африке (MENA), која обухвата преко 355 милиона људи, била је предмет бројних студија о ефектима климатских промена (Grossman, 2017).

Као последица ових појава на глобалној арени појављује се нови феномен: еколошке избеілице. Нису сви напустили своје земље (интерно расељени), али сви су привремено напустили своју домовину, ако не и трајно, са мало наде у предвидљиви повратак (Myers, 2005). Иако је немогуће за одређене сукобе експлицитно тврдити да имају само један узрок, чињеница је да је до краја 2018. године скоро 70,8 милиона појединаца било присилно расељено широм света као резултат прогона, сукоба, насиља или кршења људских права (UNHCR, 2018).

Обично се еколошки разлози избијања сукоба објашњавају различитим политичким, верско-националистичким и војним разлозима, док су, у ствари, сви у сталној сложеној међузависности. На пример, Рувени (Reuveny, 2007) је дао 38 савремених примера еколошких миграција и установио да је 19 од њих резултирало насилним сукобом, док 19 није. Ови подаци потврђују да климатска миграција није потребна ни довољна да би се објаснио сукоб (Plante et al., 2017). Међутим, многи теоретичари тврде да је клима један од многих фактора ризика који доприносе насиљу и сукобима, често у спрези са социјалним, политичким и економским факторима.

Према Извештају Међународне организације за миграције, Блиски исток и Афрички рог били су регион са највећим порастом броја избеглица у свету у 2012. години (IOM, 2019). Током 90-их година XX века, у сукобима повезаним с контролом над експлоатацијом природних ресурса и профитима оствареним од ове експлоатације, животе је изгубило више од пет милиона људи, од чега далеко највећи део у Подсахарској Африци (Santrač, 2018). Такође, у сукобима су уништени и исцрпљени значајни и углавном оскудни природни ресурси на овим просторима. Бројне студије указују и на то да су земље које су захватили сукоби и које су већ угрожене еколошким деградацијама (као што је оскудица 
воде или плодног земљишта) под највећим ризиком да доживе пораст сукоба и насиља због глобалних климатских промена (Gleditsch, 2002; Raleigh and Urdal, 2007; Van de Vliert, 2013; O'Loughlin, Linke and Witmer, 2014; Mares and Moffett, 2015). У многима од ових случајева, деградација животне средине је тачка која је на крају кулминирала међуљудским насиљем, услед страха и несигурности, перципиране оскудице или масовног пресељења, односно свих оних фактора који слабе друштвену контролу и супротстављају се механизмима које друштва користе да мирно реше спорове (Nardulli et al., 2015).

Одређени региони света изложени су конфликтима више од других. Бројне студије показале су да грађански рат у једној земљи значајно повећава вероватноћу да ће суседне државе доживети сукоб (Salehyan and Gleditsch, 2006). Конфликтни потенцијал Етиопије у сценаријима климатских промена везан је за околне државе Судан и Египат, као и остале државе које су политички нестабилне, а имају склоност ка сукобима. Оне припадају Афричком рогу, Арапском полуострву и Блиском истоку (Messer, 2010).

Претпоставља се да ће вода у будућности бити ресурс око кога ће се водити сукоби широм планете. Према извештају Уједињених нација, у свету преко 780 милиона људи нема приступ здравој пијаћој води. До 2030. године $47 \%$ светске популације ће живети у подручјима са недовољном количином воде, објављено је у извештају Оріанизације за економску сараgюу и развој (Jeftić i sar., 2018). Несташица воде и велике суше или велике поплаве, земљотреси и цунамији, уопште девастирање природних услова живота као последица еколошких фактора, најпре имају економске последице (зависност пољопривреде, индустрије, глад и сиромаштво), политичке (протести, немири и смена власти), социјеталне (миграције становништва) и коначно војне (оружани конфликти). Неретко, конфликти услед глобалних еколошких промена прерастају у политичке конфликте на међународном нивоу и укључују ширу међународну заједницу.

\section{Сукоби као последица деградације животне средине у Африци}

Према Четвртом извештају IPCС из 2007. године, посматрајући читав један век климатских промена, количина падавина у периоду од 1900. до 2005. повећала се у Северној и Јужној Америци, Северној Европи и Северној и Централној Азији, док се смањила у Јужној Африци и Јужној Азији, Медитерану и Сехелу (ІРСС, 2007). Анализирајући реги- 
он Африке, овај извештај предвиђа да ће пољопривредна производња, укључујући приступ храни, у многим афричким земљама бити озбиљно угрожена. Процене су да ће до 2020. године између 75 и 250 милиона људи бити изложено повећаном водном стресу због климатских промена, док би се у неким земљама приноси из пољопривреде могли смањити и до 50\% (IPCC, 2007).

Еколошки сукоби у Африци који настају као последица дуготрајне деградације животне средине могу се начелно поделити у три групе: 1. сукоби око природних ресурса (Мауританија, Сенегал и Сирија); 2. сукоби настали као последица климатских промена (Кенија, Етиопија) и 3. сукоби повезани са миграцијама (Јужни Судан, Еритреја). Хомер Диксон сматра да друштвени сукоб није увек лоша ствар: масовна мобилизација и грађански сукоби могу произвести прилике за корисну промену у расподели земље и богатства у процесима управљања (Homer-Dixon, 1994). Међутим, брзи, непредвидиви и сложени еколошки проблеми често анулирају напоре конструктивне друштвене и политичке реформе.

Поплаве, суше, болести и глад само су окидачи пораста политичких сукоба и конфликата. Сукоби у Етиопији, Сомалији, Јужном Судану, Анголи и у другим државама, очит су пример утицаја екстремних климатских појава на безбедност држава, али и њихових суседа, па и читавог региона. Према извештају Међународне организације за избеглице (ИОМ), због конфликата у Конгу, Јужном Судану и Сомалији велики је пораст избеглица и у Бурундији, Етиопији, Руанди, Судану и Уганди. Само у Кенији постоји највећи избеглички камп са око 600.000 избеглица из Сомалије (IOM, 2019), што додатно угрожава безбедност ове државе, која је и сама разорена сукобима око ресурса. Ови људи су највећим делом сиромашни, недовољно социјално укључени и економски неразвијени и врло често и сами животно угрожени, због чега често немају могућности за напуштање тих подручја или се крећу унутар државе, односно региона. Незадовољство које проузрокују сиромаштво и глад обично ескалира политичким немирима. С друге стране, они који су због недостатка ресурса, еколошке катастрофе, политичких немира и/или оружаних сукоба, приморани на избеглиштво, постају проблем домаћина. Долазак великог броја избеглица у један регион доводи до пораста притисака на ресурсе и економију тог региона, што често узрокује нове конфликте (Етиопија и Еритреја, Кенија и Сомалија).

Специфичност Африке јесте и у томе што већина становништва живи и зависи од пољопривреде, те је већи део популације сконцентрисан у руралним пределима, док сточарство подразумева номадски начин живота. У Кенији је дошло до ескалације насиља између заједница 
Покомо и Орма, због дуготрајног спора у вези са земљом и изворима воде око реке Тане (Jeftić i sar., 2018). Покомо заједницу претежно чине пољопривредници и риболовци, који живе дуж реке Тане. Орма су номадски пасторалисти који се крећу са једног места на друго како природа диктира, обично у потрази за пашњаком и водом за своју стоку, која им је основни извор средстава за живот (Shaiye, 2012). Река Тана је важно подручје за пасторалисте из читаве Етиопије, који у време суше мигрирају у потрази за водом и пашњаком. Између ових племена избијали су сукоби последње три деценије, који су у новије време интензивирани увозом оружја из околних земаља. Само током сукоба 2012. године погинуло је више од 110 људи, а на хиљаде је расељено (Shaiye, 2012). Номадски и полуномадски начин живота карактеристичан је за многе афричке земље, као што су Етиопија, Сомалија, Нигерија и Уганда.

Не трпи само Африка последице климатских промена и оскудице природних ресурса. Деградација животне средине има озбиљне последице на људско здравље, економски развој, али и стратешки значај за државе које своју моћ заснивају на природним ресурсима као што су вода, нафта, природни гас, руде и самим тим су узрок конфликата. Узрок Заливског рата 1991. године је у покушају Ирака да доминира Персијским заливом и поврати доминацију над Кувајтом. Сукоби у Јужном Судану 2012. године око нафтних поља натерали су бројне Суданце у избеглиштво, јер им је због војних сукоба вода била недоступна (Jeftić i sar., 2018). Оба ова сукоба, као и други, у распону од бивше Југославије, Либерије, Сомалије и Великог језера до Бутана и Бурме, могло би се рећи да имају више везе са порастом етничког (и/или религиозног) национализма него са еколошким сукобом (Black, 2001). Између Турске и њених суседа, Ирака и Сирије, управо због воде (реке Еуфрат и Тигар) још од 1960-их, траје спор на највишем нивоу.

\section{Климатске промене, оскудица природних ресурса и сукоби у Етиопији}

Када је Етиопија у питању, климатске промене које узрокују велике суше, заједно са оскудним водним ресурсима, два су основна узрока грађанских, али и међународних сукоба у овом региону Африке. Етиопија историјски представља студију случаја засновану на доказима о томе како глад може изазвати насилни сукоб - несигурност у храни, као и начин на који политичке димензије сукоба и деструктивности стварају несигурност наредним генерацијама (Messer, 2010). 
Специфичност климе у Етиопији је смена доминације сувог ветра (харматана) у зимским месецима и монсуна током летњег периода. Будући да су главни допринос етиопској киши летњи монсуни (74\% годишње кише), њихова слабост или изостанак имају катастрофалне последице за источну Африку (Comenetz and Caviedes, 2002). Осамдесет процената становништва Етиопије и даље зарађује за живот на копну, што резултира тиме да је већина становништва под великим утицајем климе (Messer, 2010). Тако је Ел Ниғо, у периоду од 1970-их до краја 1990-их, узроковао дуготрајне суше у Етиопији, праћене глађу и политичким превирањима, која су резултирала радикалним променама владе, сецесијом и масовним миграцијама становништва. Многи сматрају да је пад етиопског цара Хајле Селасија (1974) и његова замена војним режимом подстакнута социјалним немирима услед суша и очекивањима да политика реши круцијална животна питања. Политички и друштвени догађаји нису се завршили сменом власти, већ су погоршани даљим догађајима и политичким превратима (свргавањем Менгисту Хајле Маријама), односно оскудицом у храни услед суша које су произвеле последице Ел Ниға 1976-77, 1982-83, 1991-93. и 1997-98. године. То само показује да стварни узроци незадовољства нису били политички разлози.

Као што је уобичајено у таквим ситуацијама, недостатак хране и немогућност политичких актера да реше проблем глади и болести, изазвао је грађанске и политичке сукобе. Након иницијалне реакције владе засноване на употреби оружане силе за заустављање незадовољства, ширење регионалног отпора против војске сузбијало се административним мерама, од којих је најдуготрајнија и најдеструктивнија била реорганизација административних граница (Comenetz and Caviedes, 2002). Недуго затим глад је у тој мери завладала да је становништво почело да мигрира у суседне земље. Прилив избеглица може повећати ризик од сукоба, посебно грађанског рата који, по дефиницији, укључује државу као актера. Међутим, многи постулирани механизми који повезују избеглице са већим ризиком таквог сукоба односе се на тензије са локалним становницима (Bove et al., 2018). Дуги периоди суше током деведесетих година узроковали су пораст политичког насиља у Етиопији. По неким проценама, у периоду 1997-98. године суша коју је изазвао још један Ел Ниюо коштала је готово 28 милиона долара штете (Comenetz and Caviedes, 2002). Ову сушу пратила је катастрофална поплава 1998. године, која је надокнадила недостатак хране. Поред тога, било је руралног егзодуса и миграција градова, погоршаних расељавањем скоро 350.000 Етиопљана који су испливали из пограничног региона са Еритрејом када су гранични спорови довели до оружаних непријатељстава између две земље (Comenetz and Caviedes, 2002). Еколошке миграције 
врше додатни притисак на ресурсе на чијој се територији налазе, што изазива нове сукобе (борба за ресурсе), овај пут са домицилним становништвом на граници са Еритрејом.

У случају Етиопије, климатске промене које узрокују еколошку деградацију воде и земљишта, не само да су узрок незадовољства, већ су додатно погоршале и продубиле политичке сукобе. Другим речима, климатска криза узроковала је политичку кризу, а један од начина на који је влада одговорила на оба ова проблема било је наметање политике миграције. Према подацима Међународне организације за миграције, у просеку 820.000 људи истерано је из својих домова у региону Гедео, а 150.000 на западу региона Оромија (IOM, 2019). Тако је Етиопија због грађанских сукоба, поред добровољних миграција, била суочена и са принудном политичком миграцијом и њеним последицама. Поред унутрашњих политичких сукоба са циљем промене власти, ове мере изазвале су међународне граничне сукобе две нације.

Појаве еколошких деградација на афричком континенту додатно компликују проблем приступачности пијаћој води. Река Нил пролази кроз 11 земаља Централне и Источне Африке: Египат, Судан, Јужни Судан, Етиопију, Еритреју, Бурунди, Конго, Кенију, Руанду, Уганду, Танзанију. У Судану и Етиопији у порасту је индустријска производња, што захтева повећање потрошње воде Нила у циљу производње електричне енергије, као и потребе развоја пољопривреде. Етиопија је планирала да изгради систем брана на Нилу, чиме би се обезбедило наводњавање додатног пољопривредног земљишта за потребе производње хране за растућу популацију. Томе се оштро супротставља Египат, који сматра да је постојећим уговорима стекао законско право да располаже водом Нила, па свако непоштовање уговора сматра директним нападом на свој национални интерес (Ostojić, 2016). Наиме, у току 1929. године (измењен 1959. године после стицања независности Судана) потписан је уговор између Велике Британије и тадашње колоније Египта, којим је дефинисано коришћење воде реке Нила, при чему је Египту обезбеђено 55 милијарди м ${ }^{3}$ воде годишње, а Судану 18 милијарди (Ostojić i Blagojević, 2011). Остале државе у сливу ове реке немају право коришћења воде, па долази до пораста тензија. Због пораста потреба за водом, Египат тражи ревизију уговора из 1959. године и повећање удела у коришћењу воде, док се остале државе у сливу томе противе.

Власти у Етиопији сматрају да је Плави Нил, који извире у Етиопији, национални ресурс са којим могу слободно да располажу. „Базен горњег Плавог Нила налази се у етиопском горју, који је најважнији подслив Нила. Типично током јула-октобра око $80 \%$ укупног тока реке Нил про- 
тиче у Асуан у Египту, који долази из реке Плави Нил“ (Elsanabar and Abdelkader, 2015, стр. 2). Плави Нил као природни ресурс је од виталног значаја за развој индустрије и пољопривреде у Етиопији. С друге стране, Египат се плаши да ће му етиопски план изградње огромне хидроелектране на Плавом Нилу ускратити довољне количине воде.

С обзиром на њен стратешки положај, политичко-географска питања Етиопије била су предмет велике међународне забринутости, посебно за САД и Европску унију, које су од 2005. године уложиле милионе у изградњу безбедносних мера, као што су дистрибуција хране и помоћ најсиромашнијима (Young, 2004).

\section{Закључак}

Питања животне средине имају велику улогу у развоју конфликата, а њена деградација лако може бити основни узрок сукоба. Проблем је у томе што је у сукобима тешко изоловати одређени узрок, а да није у међузависности са другим узроцима. Анализирајући сукобе у једном ширем контексту, може се видети да углавном економски фактори: сиромаштво, недостатак хране, неприступачност природних ресурса подстичу незадовољство, које уз етничке и верске разлоге кулминира политичким немирима, па чак и оружаним сукобима.

Јасно је да деградација животне средине има снажан утицај на друштвене структуре и политичку стабилност. Зато је конфликте неопходно анализирати у дужем временском периоду и на тај начин повезати климатске промене, односно борбу за ресурсе, са политичким и друштвеним немирима, који често ескалирају у оружане сукобе. Велика међузависност узрока конфликата пружа слику о томе да се данашњи конфликти морају сагледавати много шире него раније (слика 1). Политичке и друштвене промене изазване су пре свега економским, односно еколошким факторима (борба за ресурсе), као у случају Кеније, док с друге стране, политички фактори (оружани сукоби), као у Јужном Судану, изазивају еколошку кризу, односно немогућност једнаког приступа природним ресурсима (води).

Посматрајући конфликте у једној широј констелацији, Етиопија је случај где су сви фактори у међусобној зависности, од еколошких промена, политичке борбе за власт и промене режима, социјалног фактора (миграције) до војног сукоба са Еритрејом. Етиопија је најбољи пример како деградација животне средине и оскудица ресурса изазивају конфликте и политичке промене не само унутар земље, већ и пограничне сукобе (Еритреја) и међународне спорове (Нил). Узрок свих ових кон- 
фликата јесте деградација животне средине и борба за оскудне ресурсе, а последице су све веће еколошке миграције становништва. Међутим, миграције не само да не решавају сукобе, већ могу бити извор нових сукоба, као у случају Етиопије и Еритреје. Пораст миграната у другом региону, уз могућу појаву националне, етничке, верске или расне нетрпељивости, може изазивати притисак на постојеће ресурсе, њихово исцрпљивање и самим тим нове конфликте. Конфликти, поготово оружани сукоби (коришћење ресурса, бомбрадовање осиромашеним уранијумом, рушење енергетске инфраструктуре), додатно исцрпљују и уништавају природне ресурсе и остављају негативне последице на животну средину. Тако улазимо у један зачарани круг узрока и последица који су у сталној међусобној интеракцији и сложеној међузависности (слика 1).

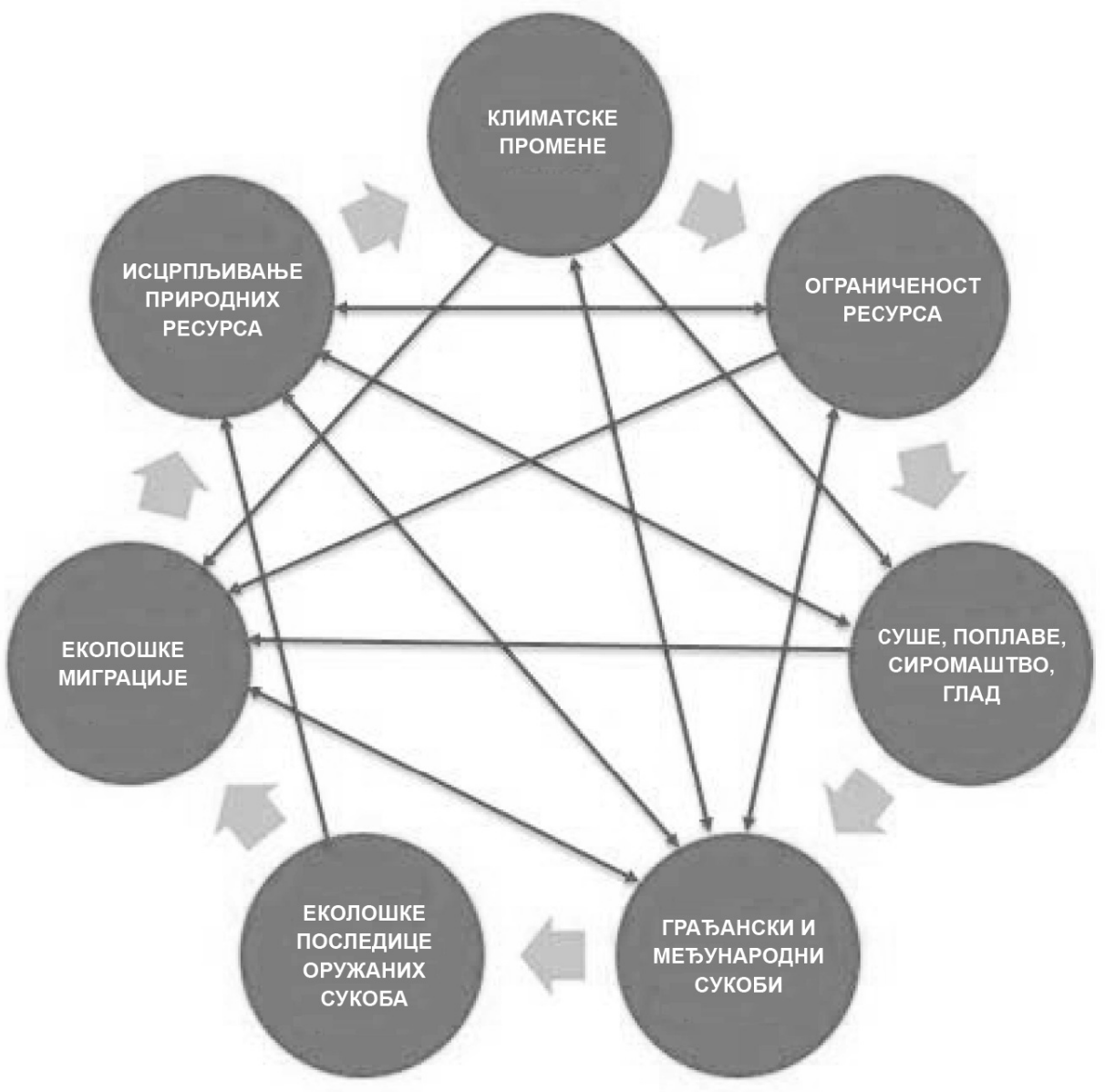

Слика 1. Климатске промене, миграције и сукоби 
Државе угрожене климатским променама морају да буду спремне на прилагођавање последицама деградације животне средине, али и да дају допринос њиховој превенцији и ублажавању, било мерама пошумљавања као у случају Етиопије (садња 350 милиона стабала), заједничким пројектима наводњавања, до решавања проблема салинизације земљишта. Прилагођавање еколошким променама је продуктивно кад постоји развој путем демократских и економских процеса, док социјални проблеми (сиромаштво, дискриминација, етничке и верске поделе) негативно утичу на друштвено окружење и продубљују сукобе. Ово се негативно одражава не само на сукобе и угрожавање људских права на слободу и живот, већ и на сам екосистем. Због грађанских немира, владе бројних држава, али и целокупна међународна заједница, улажу напоре у решавање политичких и социјалних конфликата, уместо у превенцију и решавање еколошких проблема, у чијим коренима и леже узроци друштвеног незадовољства и самих сукоба. 


\section{ЛИТЕРАТУРА}

Black, R. (2001). Environmental refugees: myth or reality? New Issues in Refugee Research Working Paper No. 34. UNHCR, Geneva. Преузето 10. августа 2019. ca: https://www.unhcr.org/research/ RESEARCH/3ae6a0d00.pdf

Bove, V., Bohmelt, T., and Gleditsch, K. (2018) Blame the victims? Refugees, state capacity, and non-state actor violence, Journal of Peace Research. Преузето 16. октобра 2019. ca: https://www.researchgate.net/ publication/327271050_Blame_the_victims_Refugees_state_capacity_ and_non-state_actor_violence

Comenetz, J., and Caviedes, C. (2002). Climate variability, political crises, and historical population displacements in Ethiopia. Global Environmental Change Part B: Environmental Hazards, 113-127.

Elsanabar, M. H., and Abdelkader T., A. (2015). Hydrological And Environmental Impacts of Grand. Eighteenth International Water Technology Conference IWTC18. Преузето 12. августа 2019. са: http://iwtc.info/wp-content/uploads/2015/04/80.pdf

Gleditsch, K. (2002) All International Politics is Local: The Diffusion of Conflict, Integration, and Democratization, University of Michigan Press, ISBN 978-0-472-11267-8

Grossman, L. (2017). Climate Change and Conflict: The Relationship Between Government Response to Climate Change and Civil Unrest in the Middle East and North Africa. Department of Political Science and International Affairs of the University of Mary Washington. Преузето 10. октобра 2019. ca: https://cas.umw.edu/polisci/

Homer-Dixon, T. F. (1994). Environmental Scarcities and Violent Conflict: Evidence from Cases. International Security 19, 5-40.

IOM. (2019). East Africa and the Horn of Africa. Intenational Organization of Migration. Преузето 1. avgusta 2019. ca https://www.iom.int/eastafrica-and-horn-africa

IPCC (2007). AR4 Climate Change 2007: Synthesis Report. IPCC. Intergovernmental Panel on Climate Change. Преузето 10. октобра 2019. ca: HYPERLINK "https://www.ipcc.ch/report/ar4/syr/" https:// www.ipcc.ch/report/ar4/syr/

IPCC (2014). AR5 Synthesis Report: Climate Change 2014. IPCC. Intergovernmental Panel on Climate Change. Преузето 10. октобра 2019. ca: https://www.ipcc.ch/report/ar5/syr/

Jeftić, Z., Mišev, G., Stanojević, P., i Obradović, Ž. (2018). Savremeni konflikti i njihove tendencije. Vojno delo, 7/2018, 23-40. 
Jovanović-Popović,D.(2013)Environmentand security:Theconceptofecological and environmental security. HYPERLINK "http://176.222.236.226/ doaj?func=issues\&jId=88657\&uiLanguage $=$ en" Zbornik Matice srpske $z a$ društvene nauke, 103-118.

Mares, D., and Moffett, K. (2015). Climate change and interpersonal violence: A "global" estimate and regional inequities. Climatic Change, 297-310. Messer, E. (2010). Climate Change and Violent Conflict: A critical literature review. Boston: Oxfam America Inc, Headquarters. Преузето 10. октобра 2019. ca: https://www.oxfamamerica.org/static/oa3/files/climate-change-andviolent-conflict.pdf

Myers, N. (2005). Environmental refugees: an emergent security issue. Environment and Migration. Prague: 13th Economic Forum. Преузето 8. августа 2019. ca: https://www.osce.org/eea/14851?download=true

Nardulli, P., Peyton, B., and Bajjalieh, J. (2015). Climate change and civil unrest: The impact of rapid-onset disasters. Journal of Conflict Resolution, 59(2), 310-335.

O'Loughlin, J., Linke, A., and Witmer, F. (2014). Effects of temperature and precipitation variability on the risk of violence in sub-Saharan Africa, 1980-2012. Proceedings of the National Academy of Sciences. Преузето 9. септембра 2019. ca: https://www.ncbi.nlm.nih.gov/pmc/articles/ PMC4250158/

Ostojić, G. (2016). Klimatske promene i nacionalna bezbednost. Vojno delo, 7, 45-67.

Ostojić, G., i Blagojević, M. (2011). Primena hegemonije u rešavanju međunarodnih sporova oko resursa pijaće vode. Međunarodni problemi, 3, 359-391.

Parfenova, E., Tchebakova, N., and Soja, A. (2019). Assessing landscape potential for human sustainability and 'attractiveness' across Asian Russia in a warmer 21st century. IOP Publishing, Environ. Res. Lett., 14, 2-14.

Plante, C., Allen, J., and Anderson, C. (2017). Effects of Rapid Climate Change on Violence and Conflict. Policy, Politics, and Governance, Future Climate Change Scenarios, Communication Online Publication. 1-27.

Raleigh, C., and Urdal, H. (2007). Climate change, environmental degradation, and armed conflict. Political Geography, 26, 674-694.

Reuveny, R. (2007). Climate change-induced migration and violent conflict. Political Geography, 26, 656-673.

Salehyan, I. and Gleditsch, K. (2006) Refugees and the Spread of Civil War, Cambridge University Press. Преузето 15. октобра 2019. ca: https://www. cambridge.org/core/journals/international-organization/article/refugeesand-the-spread-of-civil-war/661D0F75EBC76E48585151BEBF858436 
Santrač, S. (2018). Ratovi za resurse u novom geološkom dobu. Urban Logic Centre Преузето 18. avgusta 2019. ca: http://urbanlogic.edu.rs/index. $\mathrm{php} / \mathrm{sr}$-yu/zurnal/5-ratovi-za-resurse-u-novom-geoloskom-dobu

Shaiye, A. (2012). Factors Influencing Conflict Between Communities The Case Study Of Orma And Pokomo Communities In The Tana Delta Of Tana River County, Kenya. University of Nairobi. Преузето 18. августа 2019. ca: http://erepository.uonbi.ac.ke/handle/11295/62235

UNHCR (2018) Global trends 2018. United Nations High Commissioner for Refuges. Преузето 11. oktobra 2019. ca: https://www.unhcr. org/5d08d7ee7.pdf

Van de Vliert, E. (2013). Climato-economic habitats support patterns of human needs, stresses, and freedoms. Behavioral and Brain Sciences 36, str. $465-521$.

Young, H. (2004). Ethiopia 2003: Towards a Broader Public Nutrition Approach, Humanitarian Exchange Magazine 27. Преузето 10. oktobra 2019. ca: www.odihpn.org/report.asp?id=2647. 


\title{
THE IMPACT OF CLIMATE CHANGE ON POLITICAL UNRESTS AND CONFLICTS IN AFRICA: A CASE STUDY OF ETHIOPIA
}

\author{
Gordana Mišev, PhD Student \\ University of Belgrade, Faculty of Security Studies
}

\section{Summary}

Security challenges, risks, and threats, beyond traditional forms, have become so complex that understanding them is a way of identifying specific types of interaction that threaten security. Climate change and global warming can have serious consequences for human health, social and economic development. Intensifying climate change can increase the risk of political unrest and conflict in countries whose economic and social development is conditioned by free access to natural resources. The cause of conflict is never easy to determine because it is a set of different factors that interact with one another. A brief overview of conflicts in Africa with a particular focus on conflicts in Ethiopia and the region is presented. This paper reports on the complexity and interdependence of climate change and its consequences on political decisions, social unrest, forced migration and civil and international conflicts.

Keywords: climate change, political conflicts, migration, Africa, Ethiopia. 